\title{
TRMM-based rainfall temporal analysis over Italy
}

\author{
T. Caloiero ${ }^{1}(1) \cdot$ G. N. Caroletti ${ }^{2}$ (1) R. Coscarelli ${ }^{2}$ (1)
}

Received: 30 March 2020 / Accepted: 13 June 2020 / Published online: 23 June 2020

(c) Springer Nature Switzerland AG 2020

\begin{abstract}
Rainfall is an irregular phenomenon showing large spatial variability. Unfortunately, spatially distributed data are not always available, because rain gauge networks are not continuously dense and adequately distributed, and they provide only point measurements. In this work, the temporal variability of rainfall in Italy has been investigated using the Tropical Rainfall Measuring Mission monthly product for the period 1998-2018. Within this aim, more than 650 grid points falling within the Italian territory have been selected. In order to evaluate the presence of trends and their significance, the monthly, seasonal and annual rainfall series were analysed at each grid point with the Mann-Kendall nonparametric test and the Theil-Sen estimator. The broad extension of the area under investigation allowed a better understanding of rainfall trend patterns over space. At annual scale, results evidenced few relevant trends, either positive or negative, involving central Italy (negative trend) and southern Italy (positive trend). A similar trend behaviour has been identified, at seasonal scale, in autumn, with a clear spatial difference between the north and the south of Italy, in winter for the negative trend and in spring for the positive one. In summer, only few grid points in central Italy showed a significant increasing trend.
\end{abstract}

Keywords Rainfall $\cdot$ TRMM $\cdot$ Trend $\cdot$ Italy

\section{Introduction}

Due to the impact of climate change on long- and shortterm variability of water resources, in the last decades the analysis of the spatial and temporal behaviour of rainfall has become paramount, especially for water management purposes. In fact, climate change could influence extreme events, with an increase in the frequency and in the magnitude of these events, and cause changes in mean renewable water supplies [1]. Within this context, trend analysis has been widely used to detect the possible consequences of climate change in different hydrological temporal series in the Mediterranean Basin, which is considered a major hot spot of climate change [2]. In fact, the Mediterranean Basin is placed in a transition area, and its climate is influenced by both the mild and rainy climate of central Europe and the arid climate of North Africa [1]. Results of trend analysis performed on the Mediterranean basin evidenced a diffuse decrease in the annual rainfall [3] although with some differences between the eastern and western areas of the region $[4,5]$. In fact, while the western and central Mediterranean is characterized by a negative rainfall trend [6] although irregular and highly variable across the decades, the eastern region presents contrasting results, with positive rainfall tendencies in some areas $[7,8]$ and negative trends in others such as Israel $[9,10]$.

Italy is particularly important among the different areas of the Mediterranean Basin because it is located in the centre of the western Mediterranean and because of its particular shape extending over a wide latitude from north to south. Following the Koppen-Geiger classification [11], the climate of Italy is mainly classified as Csa, i.e.

T. Caloiero, tommaso.caloiero@isafom.cnr.it; G. N. Caroletti, giulio.nils.caroletti@irpi.cnr.it; R. Coscarelli, roberto.coscarelli@irpi.cnr.it | ${ }^{1}$ Institute for Agriculture and Forest Systems in the Mediterranean (CNR-ISAFOM), National Research Council of Italy, 87036 Rende, CS, Italy. ${ }^{2}$ Research Institute for Geo-hydrological Protection (CNR-IRPI), National Research Council of Italy, 87036 Rende, CS, Italy. 
a warm temperate Mediterranean climate with dry, warm summers (above $22^{\circ} \mathrm{C}$ on average) and moderate, wet winters. The northern and north-eastern areas of Italy have a Cfa climate, which is similar to the Csa, but with humid conditions all year round. Since 1998 data collection has been managed independently by the single regions, the main administrative division of the Italian State. For this reason, rainfall trend analysis in Italy has been mainly conducted at a regional scale. The majority of these studies analysed rainfall trends at the annual timescale, evidencing a decrease in annual rainfall especially in the southern regions of the country [12] and in some regions of Central Italy such as Abruzzo [13] and Marche [14]. At the same time, a different trend behaviour was identified at the seasonal timescale in southern Italy, with decreasing rainfall amounts in the winter-autumn period and a rainfall increase in the summer months, such as in the studies performed in Campania [15, 16], Basilicata [17], Sicily [18], Calabria [19] and Sardinia [2, 20].

In order to overcome the lack of spatially distributed data, different sources of rainfall data must be considered. For example, in recent years, the increased availability of meteorological satellites has opened up new opportunities for the regular monitoring of climate variables in regions with complex orography and scarce human settlements, where stations are not enough to provide the necessary information. Within this context, temperature, soil moisture and rainfall have been estimated in some studies using satellite products [21]. With regard to rainfall, several satellite products have been evaluated on multiple spatial and temporal scales, e.g. Climate Prediction Center morphing technique (CMORPH) precipitation; East Asian multi-satellite Integrated Precipitation (EMSIP); Precipitation Estimation from Remotely Sensed Information using Artificial Neural Networks (PERSIANN); and Tropical Rainfall Measuring Mission's Multi-satellite Precipitation Analysis (TMPA). The latter, especially, has been one of the most significant contributions in the last 20 years [22], also developed with the specific goal of measuring precipitation over the oceans and tropics [23].

The aim of the present paper is to perform a trend analysis in Italy at national scale, thus overcoming the problem of the different regional databases. With this aim, monthly, seasonal and annual TRMM rainfall data from 1998 to 2018 have been analysed by means of the Mann-Kendall nonparametric test and the Theil-Sen estimator.

\section{Materials and methods}

Among the several available satellite data products, one of the most important is the Tropical Multi-satellite Precipitation Analysis (https://gpm.nasa.gov/trmm), often defined as TRMM (TMPA) or simply TRMM [24]. This database includes daily and monthly precipitation values, at all longitudes, for latitudes ranging from $50^{\circ} \mathrm{S}$ to $50^{\circ} \mathrm{N}$, and from 1 January 1998 to 31 December 2019, when it has been fully replaced by the Integrated Multi-satellitE Retrievals for GPM (IMERG), whose record spans from June 2000 to present. Both TRMM and IMERG data are adjusted at the monthly timescale through Global Precipitation Climatology Center (GPCC) rain gauges. TRMM data have been tested and validated in many studies (e.g. $[25,26])$, and they have been used as the satellite source for merged products like Climate Hazards Group InfraRed Precipitation with Station Data (CHIRPS; [27, 28]). TRMM has been used successfully at both meteorological and climatological timescales in the Mediterranean region (e.g. [29-31]). In Fig. 1, the mean annual rainfall evaluated for each grid point falling within the Italian territory is shown.

In order to analyse possible trend in annual rainfall series two nonparametric tests for trend detection have been used: the Theil-Sen (TS) estimator [32] for the evaluation of the slopes of the trends and the Mann-Kendall (MK) test $[33,34]$ for the assessment of the statistical significance.

In particular, the TS estimator has been selected because it is not susceptible to the influence of extreme values, and thus, it is more powerful than linear regression methods in trend slope evaluation in the presence of outliers in the series.

The first step in the calculation of the TS estimator is to evaluate the values of $Q_{i}$ given $N$ pairs of data:

$Q_{i}=\frac{x_{j}-x_{k}}{j-k}$ for $i=1, \ldots, N$,

in which $x_{j}$ and $x_{k}$ are the data values at times $j$ and $k$ (with $j>k)$, respectively.

If there is only one datum in each time period, then $N=n(n-1) / 2$, where $n$ is the number of time periods. If there are multiple observations in one or more time periods, then $N<n(n-1) / 2$, where $n$ is the total number of observations.

The TS estimator is then computed as the median $Q_{\text {med }}$ of the $N$ values of $Q_{i}$, ranked from the smallest to the largest.

$Q_{\text {med }}= \begin{cases}Q_{[(N+1) / 2]} & \text { if } N \text { is odd } \\ \frac{Q_{[N / 2]}+Q_{[(N+2) / 2]}}{2} & \text { if } N \text { is even. }\end{cases}$

The $Q_{\text {med }}$ sign reveals the trend behaviour, while its value indicates the magnitude of the trend.

In order to evaluate the significance of the trend, the statistic $S$ must be first estimated as: 


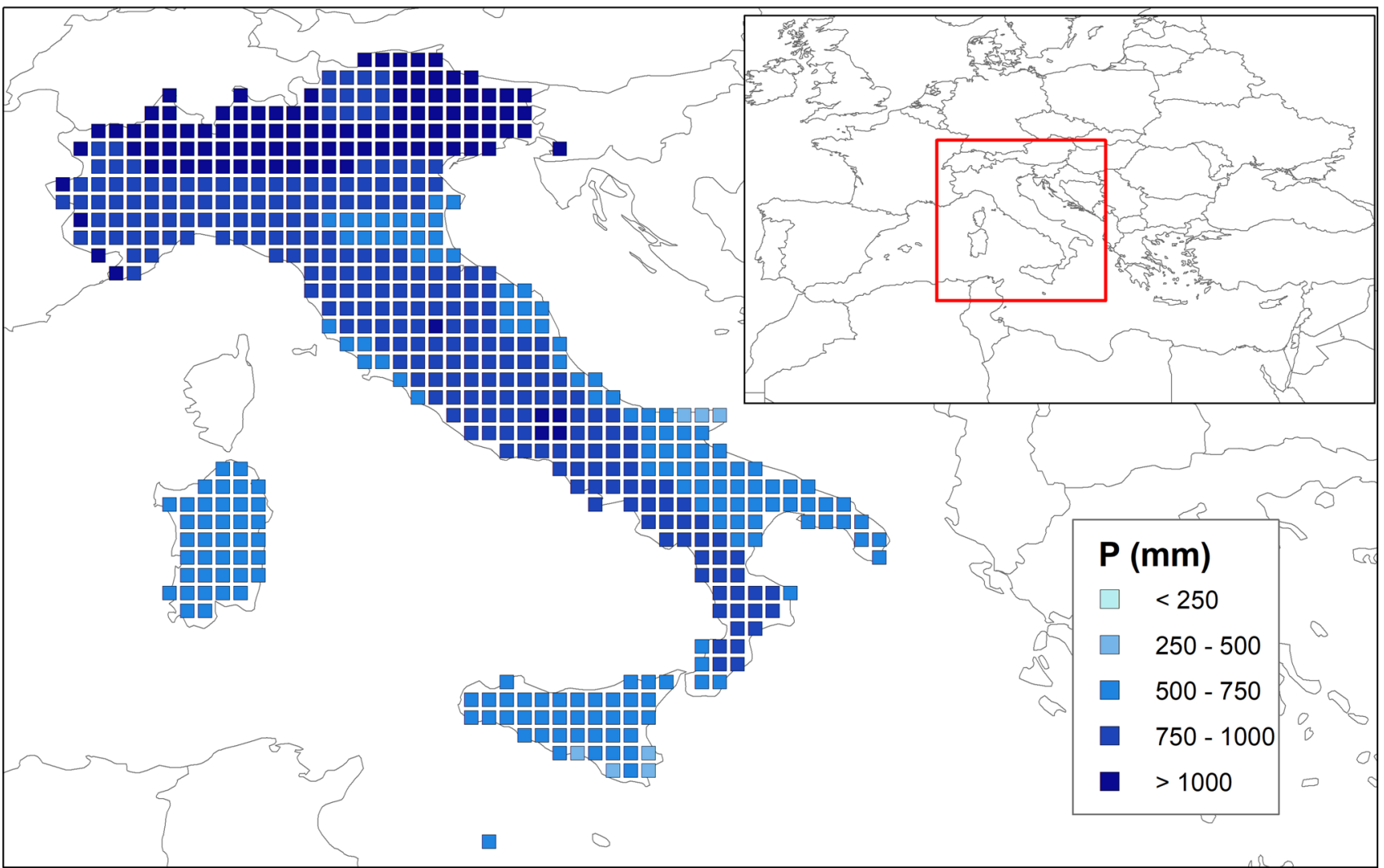

Fig. 1 Localization of the study area and spatial distribution of the average annual precipitation

$S=\sum_{i=1}^{n-1} \sum_{j=i+1}^{n} \operatorname{sgn}\left(x_{j}-x_{i}\right) ;$ with $\operatorname{sgn}\left(x_{j}-x_{i}\right)=\left\{\begin{array}{cc}1 & \text { if }\left(x_{j}-x_{i}\right)>0 \\ 0 & \text { if }\left(x_{j}-x_{i}\right)=0 \\ -1 & \text { if }\left(x_{j}-x_{i}\right)<0\end{array}\right.$

in which $x_{j}$ and $x_{i}$ are the variable values in the years $j$ and $i$ (with $j>i$ ), respectively, and $n$ is the dimension of the series.

Given independent and randomly ordered values, for $n>10$, the statistic $S$ is distributed following a normal distribution with zero mean and variance:

$\operatorname{Var}(S)=\left[n(n-1)(2 n+5)-\sum_{i=1}^{m} t_{i} i(i-1)(2 i+5)\right] / 18$

with $t_{i}$ number of ties with extent $i$.

Finally, the standardized statistic $Z_{M K^{\prime}}$ can be computed as:

$Z_{M K}=\left\{\begin{array}{ll}\frac{S-1}{\sqrt{\operatorname{Var}(S)}} & \text { for } S>0 \\ 0 & \text { for } S=0 \\ \frac{S+1}{\sqrt{\operatorname{Var}(S)}} & \text { for } S<0\end{array}\right.$.
By applying a two-tailed test, for a specified significance level $a$, the significance of the trend can be evaluated. In particular, in this work, the rainfall series have been examined for a significance level (SL) equal to $90 \%$.

\section{Results and discussion}

The results of the MK test, applied to the rainfall evaluated at different timescales, are summarized as percentages of grid points evidencing positive or negative trends (Fig. 2). In this figure and in the following ones, seasons were divided considering December, January and February as winter, March, April and May as spring, June, July and August as summer and September, October and November as autumn. At annual scale, a clear trend cannot be detected. In fact, only $4.1 \%$ and $2.5 \%$ of the grid points showed a positive or a negative significant trend, respectively. In particular, the negative trend mainly involved central Italy, with magnitude reaching values of $-50 \mathrm{~mm} / 10$ years, while south of Italy is characterized by a positive trend. Some negative trends have been also identified close to the north-eastern and north-western borders of the country (Fig. 2). 
Fig. 2 Percentages of grid points presenting positive or negative trends at different timescales and spatial results of the trend analysis at annual scale: large squares dimension indicates significant trend, small squares otherwise

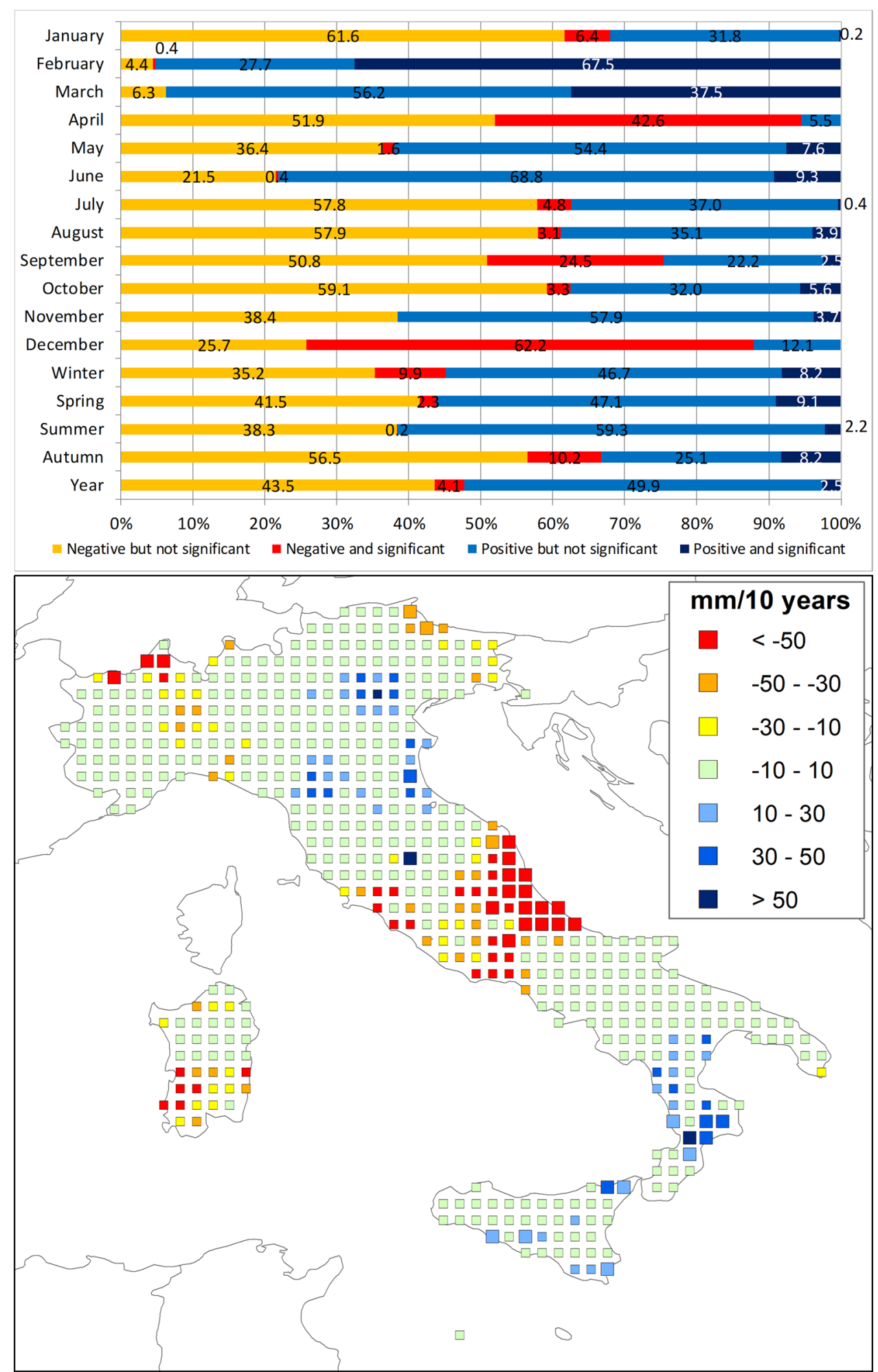

Similar results, with no marked tendencies, have also been obtained at seasonal scale. In fact, in winter, about $10 \%$ of the grid points showed significant negative values, while an opposite trend has been identified in more than $8.0 \%$ of the grid points (Fig. 2). This trend behaviour in winter is influenced by the trend distribution on the monthly scale, in which a marked difference between December and February emerged with more than $60 \%$ of the grid points evidencing negative and positive trends, respectively. Conversely, no significant positive trend has

\section{SN Applied Sciences}


been identified in December and only $0.4 \%$ of the grid points showed a negative trend in February (Fig. 2). In January, only $6.4 \%(0.2 \%)$ of the grid points evidenced a negative (positive) trend. As regards the spring months, a negative trend has been detected in April (42.6\% of the grid points), while an opposite trend has been evidenced in March (37.5\%) and, slightly, in May (7.6\%). As a result of this monthly behaviour, in spring $9.1 \%$ of the grid points showed a positive trend and only $2.3 \%$ a negative one (Fig. 2). In summer, few significant trends have been detected, with $0.2 \%$ and $2.2 \%$ of the grid points showing negative and positive values, respectively. This trend behaviour is mainly due to the June month, when more than $9 \%$ of the grid points showed significant positive values, while an opposite trend has been identified in only $0.4 \%$ of the grid points.

In the other summer months, $4.8 \%$ and $3.1 \%$ of the grid point evidenced a negative tendency and $0.4 \%$ and $3.9 \%$ a positive one in July and in August, respectively (Fig. 2). Finally, in the autumn months, a slightly prevailing positive trend has been observed in October (5.6\%) and in
November (3.7\%), while a marked opposite behaviour has been detected in September, with $24.5 \%$ of the grid points showing a negative trend. Conversely, 2.5\% (September) and $3.3 \%$ (October) of the grid points showed positive and negative significant trends, respectively. As a consequence of the monthly trends, in autumn a positive trend has been detected in $8.2 \%$ of the grid points, while $10.2 \%$ evidenced a negative one (Fig. 2).

The spatial results of the trend analysis applied to the seasonal rainfall, for a significance level equal to $90 \%$, are presented in Fig. 3. In particular, the spatial behaviour of the winter trend is similar to the annual one in central Italy, with the negative trends mainly localized on the eastern side reaching values of $-50 \mathrm{~mm} / 10$ years (Fig. 3a). Differently from the annual spatial distribution, in winter positive trends have been identified in north of Italy, with several grid points showing increases higher than $50 \mathrm{~mm} / 10$ years (Fig. 3a). As regards spring, the majorities of the positive trends have been detected in southern Italy with increasing values also between 30 and $50 \mathrm{~mm} / 10$ years, while significant negative trends have
Fig. 3 Spatial results of the trend analysis at seasonal scale: a winter, b spring, $\mathbf{c}$ summer and $\mathbf{d}$ autumn: large squares dimension indicates significant trend, small squares otherwise

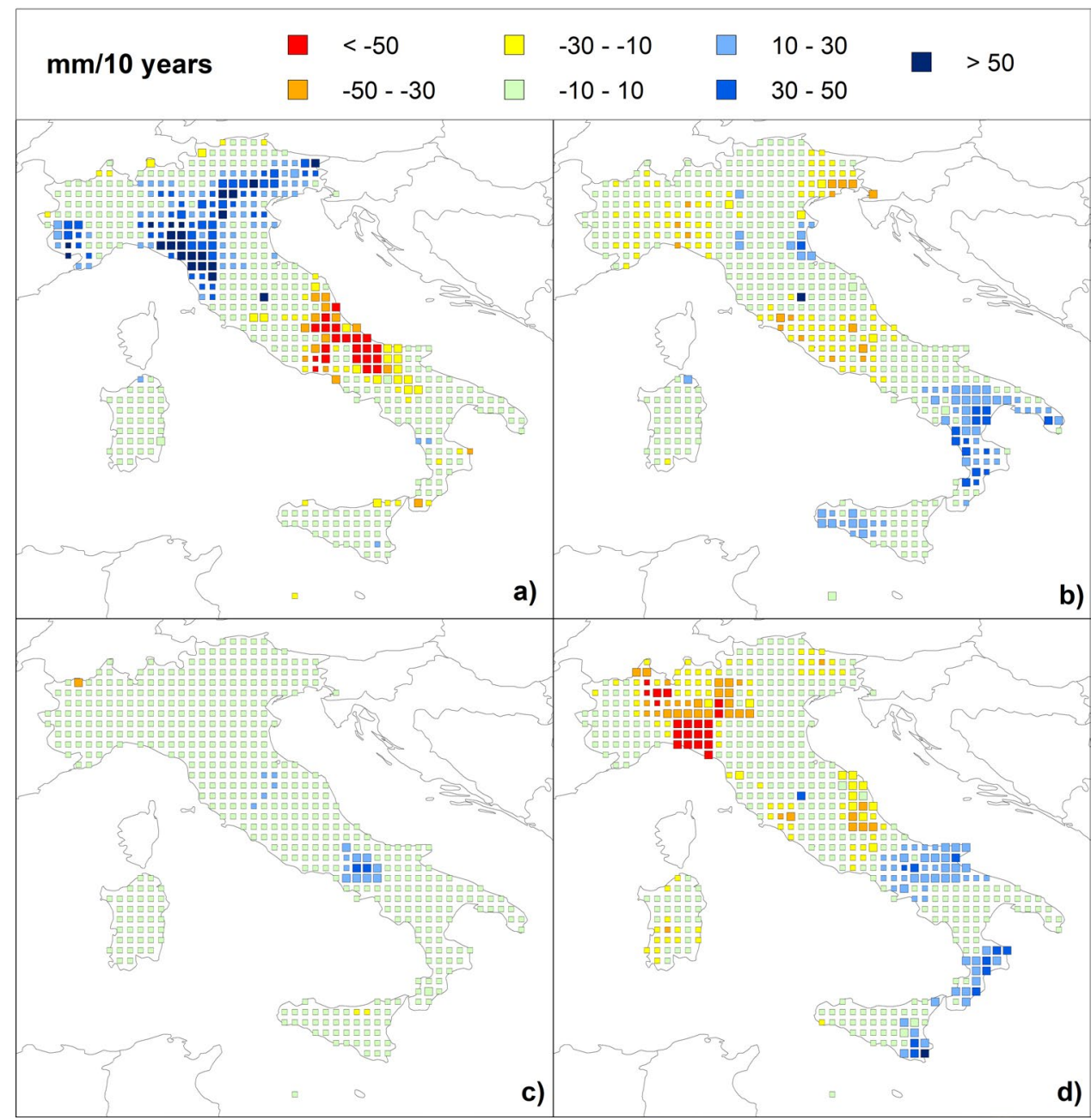


been identified in few grid points of the north-eastern side of the country (Fig. 3b). In summer, only few grid points in central Italy showed significant increasing trend, with magnitude higher than $10 \mathrm{~mm} / 10$ years (Fig. 3c). Finally, in autumn a clear spatial difference between north and south of Italy has been detected. In fact, while the northern part of the country showed a negative trend, reaching values lesser than $-50 \mathrm{~mm} / 10$ years, a positive trend has been identified in the southern areas (Fig. 3d).

On a monthly basis, remarkable negative trends have been detected in April and December with several grid points showing decreasing values of more than $50 \mathrm{~mm} / 10$ years (Fig. 4). In particular, this trend behaviour has been identified in the central and in the north-eastern side of the country in April, while it involved almost all of the country in December. February and March showed an opposite trend behaviour with respect to April and December (Fig. 4). In fact, in February, the northern and the southernmost parts of Italy showed a marked positive trend with increasing values in 10 years higher than $50 \mathrm{~mm}$. In March, this trend behaviour is less marked involving mainly the south part of the country and some areas in the eastern and the north-western sides.

In order to better appreciate the results of this study, some important remarks must be made concerning the database. First of all, the opportunity of using TRMM data for trend and interannual variability studies needs to be addressed. As TRMM is a high-resolution precipitation product, designed to provide best precipitation estimates at one point, but not a climate data record, it might not perform well in the context of trend analysis [35]. Moreover, as TRMM uses monthly gauge adjustment through the Global Precipitation Climatology Centre rain gauges (GPCC, monitoring version $6,1.0^{\circ}$ grid resolution), even if TRMM is demonstrated to reproduce reliably climate data over Italy, the trend estimates are strongly dependent on, and thus might just reflect those of, the GPCC. Concerning the first aspect, several studies have analysed the skill in TRMM in reproducing data records in the Central Mediterranean, showing correlations ranging from 0.75 to 0.96 with ground-based data [31, 36, 37]. In regard to the second issue, it must be noted that most GPCC grid cells in Italy have no rain gauges at all, with the number of rain gauges per cell in the range of $0-4$ for the whole country, much less than for other areas of Europe like Germany or Switzerland, where they are consistently at least 8-10 per grid cell [5]. For these reasons, TRMM has been used for climatological trend analysis in areas with scarce to no rain gauge availability (e.g. [38-41]).

Finally, results of this study seem to be in contrast to the ones obtained in other Italian regions, especially in the south of Italy, which evidenced a rainfall reduction in the winter months and an increase during the summer months $[15,16,42-44]$. However, they are consistent with the existing literature because TRMM data are available for the period 1998-2018, and that between 2001 and 2002 southern Italy has been hit by a long and severe drought period [45], which obviously influenced trend results, especially as it happened at the beginning of the study period. Anyway, results obtained in this study can be related to some teleconnection patterns which influence rainfall trend behaviour in the Euro-Mediterranean area (e.g. [46, 47]). For example, as regards the western Mediterranean area, several studies showed the impacts of the North Atlantic Oscillation (NAO) on rainfall (e.g. [12, $48,49])$.

\section{Conclusions}

The results of this study did not evidence a clear tendency for the entire Italian territory and for all the timescales analysed, which presented opposite trends even in those months belonging to the same season. Moreover, due to the different study periods used in the analyses, some discrepancies among the results of this study and other literature surveys have emerged. Nevertheless, the TRMM database used in this study allowed us to analyse the rainfall trend patterns over space, homogeneously and uniformly for a rather vast territory. Moreover, some outputs have considerable significance. By means of an example, the largely diffused negative trends with decreasing values of more than $50 \mathrm{~mm} / 10$ years in December, a month in which the recharge of water reservoirs usually occurs, deserve consideration. Indeed, the results of this investigation could be very useful for large-scale water management decision-makers. 


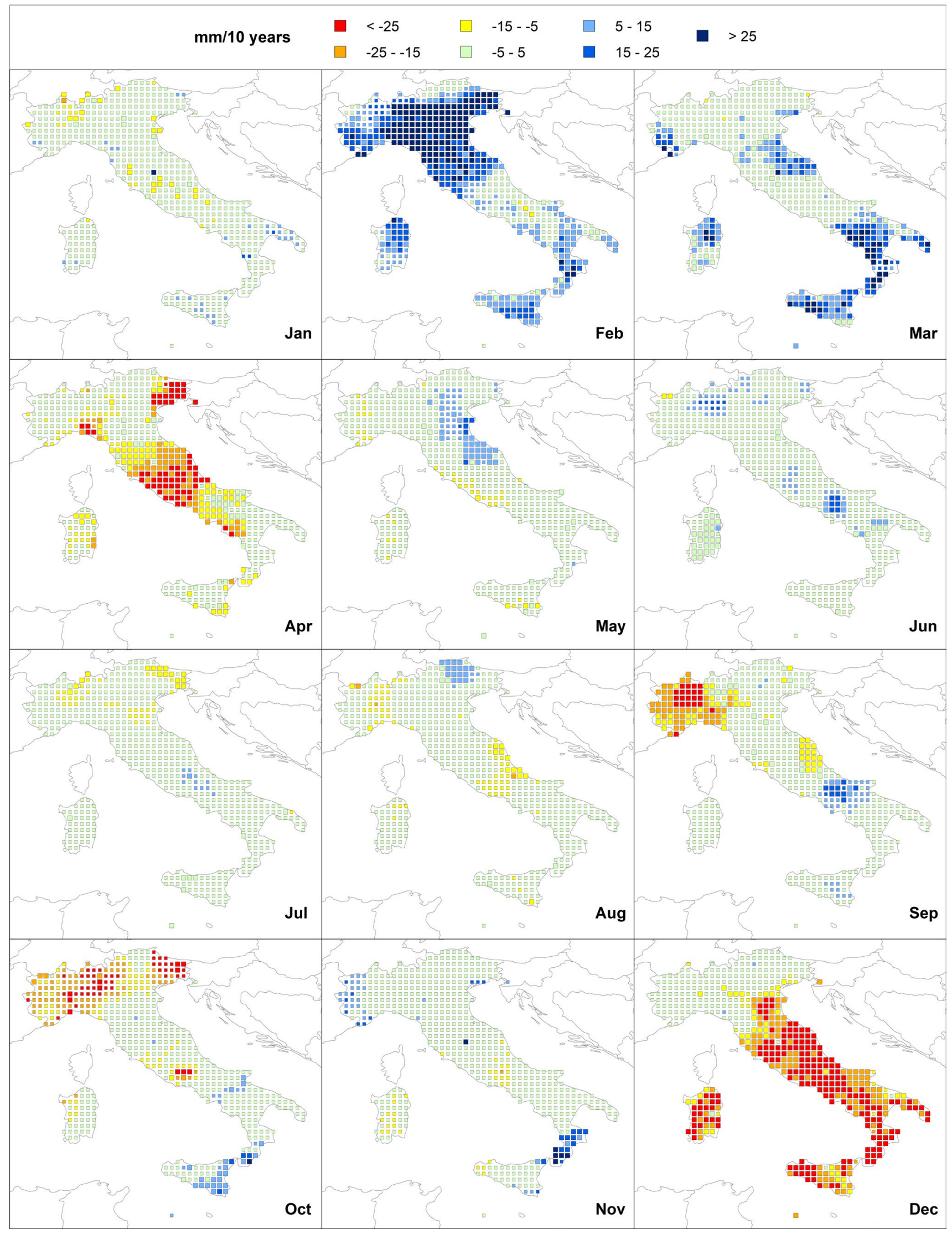

Fig. 4 Spatial results of the trend analysis at monthly scale: large squares dimension indicates significant trend, small squares otherwise 


\section{Compliance with ethical standards}

Conflict of interest On behalf of all authors, the corresponding author states that there is no conflict of interest.

\section{References}

1. IPCC (2013) Summary for policymakers. Fifth assessment report of the intergovernmental panel on climate change. Cambridge University Press, Cambridge

2. Caloiero T, Coscarelli R, Gaudio R, Leonardo GP (2019) Precipitation trend and concentration in the Sardinia region. Theor Appl Climatol 137:297-307

3. del Rio S, Herrero L, Fraile R, Penas AP (2011) Spatial distribution of recent rainfall trends in Spain (1961-2006). Int J Climatol 31:656-667

4. Zhang X, Aguilar E, Sensoy S et al (2005) Trends in Middle East climate extreme indices from 1950 to 2003. J Geophys Res 110:D22104

5. Caloiero T, Caloiero P, Frustaci F (2018) Long-term precipitation trend analysis in Europe and in the Mediterranean basin. Water Environ J 32:433-445

6. Longobardi A, Villani P (2010) Trend analysis of annual and seasonal rainfall time series in the Mediterranean area. Int J Climatol 30:1538-1546

7. Maheras $P$, Tolika K, Anagnostopoulou C, Vafiadis M, Patrikas I, Flocas H (2001) On the relationships between circulation types and changes in rainfall variability in Greece. Int J Climatol 24:1695-1712

8. Altin TB, Barak B (2014) Changes and trends in total yearly precipitation of the Antalya District, Turkey. Procedia Soc Behav Sci 120:586-599

9. Shohami D, Dayan U, Morin E (2011) Warming and drying of the eastern Mediterranean: additional evidence from trend analysis. J Geophys Res 116:D22101

10. Ziv B, Saaroni H, Pargament R, Harpaz T, Alpert P (2014) Trends in rainfall regime over Israel, $975-2010$, and their relationship to large-scale variability. Reg Environ Change 14:1751-1764

11. Köppen W (1936) Das geographische System der Klimate. In: Köppen W, Geiger R (eds) Handbuch der Klimatologie Bd. 1: Teil C. Bornträger, Berlin

12. Caloiero T, Coscarelli R, Ferrari E, Mancini M (2011) Precipitation change in Southern Italy linked to global scale oscillation indexes. Nat Hazards Earth Syst Sci 11:1-12

13. Scorzini AR, Leopardi M (2019) Precipitation and temperature trends over central Italy (Abruzzo Region): 1951-2012. Theor Appl Climatol 135:959-977

14. Gentilucci M, Barbieri M, Lee HS, Zardi D (2019) Analysis of rainfall trends and extreme precipitation in the Middle Adriatic Side, Marche Region (Central Italy). Water 11:1948

15. Diodato N (2007) Climatic fluctuations in southern Italy since 17 th century: reconstruction with precipitation records at Benevento. Clim Change 80:411-431

16. Longobardi A, Buttafuoco G, Caloiero T, Coscarelli R (2016) Spatial and temporal distribution of precipitation in a Mediterranean area (southern Italy). Environ Earth Sci 75:189

17. Piccarreta M, Capolongo D, Boenzi F (2004) Trend analysis of precipitation and drought in Basilicata from 1923 to 2000 within a Southern Italy context. Int J Climatol 24:907-922
18. Liuzzo L, Bono E, Sammartano V, Freni G (2016) Analysis of spatial and temporal rainfall trends in Sicily during the 1921-2012 period. Theor Appl Climatol 126:113-129

19. Caloiero T, Coscarelli R, Ferrari E, Mancini M (2011) Trend detection of annual and seasonal rainfall in Calabria (southern Italy). Int J Climatol 31:44-56

20. Montaldo N, Sarigu A (2017) Potential links between the North Atlantic Oscillation and decreasing precipitation and runoff on a Mediterranean area. J Hydrol 553:419-437

21. Fensterseifer C, Allasia DG, Paz AR (2016) Assessment of the TRMM 3B42 precipitation product in southern Brazil. J Am Water Resour Assoc 52:367-375

22. Liu J, Duan Z, Jiang J, Zhu AX (2015) Evaluation of three satellite precipitation products TRMM 3B42, CMORPH, and PERSIANN over a subtropical watershed in China. Adv Meteorol 2015:151239

23. Caroletti GN, Coscarelli R, Caloiero T (2019) Validation of gridded observational and modelled monthly rainfall data in Calabria (southern Italy). Remote Sens 11:1625

24. Huffman GJ, Adler RF, Bolvin DT, Gu G, Nelkin EJ, Bowman KP, Hong Y, Stocker EF, Wolff DB (2007) The TRMM multisatellite precipitation analysis (TMPA): quasi-global, multiyear, combinedsensor precipitation estimates at fine scales. J Hydrometeorol 8:38-55

25. Adler RF, Huffman G, Bolvin D (2002) TRMM and GPCP initial cross-comparison. GEWEX News 12:5-6

26. Li N, Wang Z, Chen X, Austin G (2019) Studies of general precipitation features with TRMM PR data: an extensive overview. Remote Sens 11:80

27. Funk C, Peterson P, Landsfeld M, Pedreros D, Verdin J, Shukla S, Michaelsen J (2015) The climate hazards infrared precipitation with stations - a new environmental record for monitoring extremes. Sci Data 2:150066

28. Funk C, Verdin A, Michaelsen J, Peterson P, Pedreros D, Husak G (2015) A global satellite-assisted precipitation climatology. Earth Syst Sci 7:275-287

29. Mehta AV, Yang S (2008) Precipitation climatology over Mediterranean Basin from en years of TRMM measurements. Adv Geosci 17:87-91

30. Gabella M, Morin E, Notarpietro R (2011) Using TRMM spaceborne radar as a reference for compensating ground-based radar range degradation: methodology verification based on rain gauges in Israel. J Geophys Res 116:D02114

31. Kalimeris A, Kolios S (2019) TRMM-based rainfall variability over the Central Mediterranean and its relationships with atmospheric and oceanic climatic modes. Atmos Res 230:104649

32. Sen PK (1968) Estimates of the regression coefficient based on Kendall's tau. J Am Stat Assoc 63:1379-1389

33. Mann HB (1945) Nonparametric tests against trend. Econometrica 13:245-259

34. Kendall MG (1962) Rank correlation methods. Hafner Publishing Company, New York

35. Huffman GJ (2015) Sorting out the variety of precipitation datasets. In: 2015 GSA annual meeting in Baltimore, Maryland, USA, 1-4 November 2015, Paper No. 296-4. https://gsa.confex.com/ gsa/2015AM/webprogram/Paper268654.html. Accessed 16 May 2020

36. Nastos PT, Kaposmenakis J, Philandras KM (2016) Evaluation of the TRMM 3B43 gridded rainfall estimates over Greece. Atmos Res 169:497-514

37. Kolios S, Kalimeris A (2020) Evaluation of the TRMM rainfall product accuracy over the central Mediterranean during a 20-year period. Theor Appl Climatol 139:785-799 
38. Zmijewski K, Becker R (2014) Estimating the effects of anthropogenic modification on water balance in the Aral Sea Watershed Using GRACE: 2003-12. Earth Interact 18:1-16

39. Mondal A, Lakshmi V, Hashemi H (2018) Intercomparison of trend analysis of multisatellite monthly precipitation products and gauge measurements for River Basins of India. J Hydrol 565:779-790

40. Nucifera F, Riasasi W, Permatasari AL (2019) Identification of rainfall variability using TRMM data analysis. IOP Conf Ser Earth Environ Sci 313:012043

41. Tan ML (2019) Assessment of TRMM product for precipitation extreme measurement over the Muda River Basin, Malaysia. HydroResearch 2:69-75

42. Brunetti M, Caloiero T, Coscarelli R, Gullà G, Nanni T, Simolo C (2012) Precipitation variability and change in the Calabria region (Italy) from a high resolution daily dataset. Int J Climatol 32:57-73

43. Caloiero T, Buttafuoco G, Coscarelli R, Ferrari E (2015) Spatial and temporal characterization of climate at regional scale using homogeneous monthly precipitation and air temperature data: an application in Calabria (southern Italy). Hydrol Res 46:629-646

44. Piccarreta M, Pasini A, Capolongo D, Lazzari M (2013) Changes in daily precipitation extremes in the Mediterranean from 1951 to 2010: the Basilicata region, southern Italy. Int J Climatol 33:3229-3248
45. Buttafuoco G, Caloiero T, Coscarelli R (2015) Analyses of Drought events in Calabria (Southern Italy) using standardized precipitation index. Water Resour Manag 29:557-573

46. Hoy A, Schucknecht A, Sepp M, Matschullat J (2014) Large-scale synoptic types and their impact on European precipitation. Theor Appl Climatol 116:19-35

47. Fleig AK, Tallaksen LM, James P, Hisdal H, Stahl K (2015) Attribution of European precipitation and temperature trends to changes in synoptic circulation. Hydrol Earth Syst Sci 19:3093-3107

48. Trigo IF, Davies TD, Bigg GR (2000) Decline in Mediterranean rainfall caused by weakening of Mediterranean cyclones. Geophys Res Lett 27:2913-2916

49. Ferrari E, Caloiero T, Coscarelli R (2013) Influence of the North Atlantic Oscillation on winter rainfall in Calabria (southern Italy). Theor Appl Climatol 114:479-494

Publisher's Note Springer Nature remains neutral with regard to jurisdictional claims in published maps and institutional affiliations. 